\author{
Dorota Krystyna Rembiszewska \\ Polska Akademia Nauk w Warszawie \\ Instytut Slawistyki \\ ORCID: 0000-0003-0339-0879; e-mail: dorota.rembiszewska@ispan.waw.pl

\section{Janusz Siatkowski} \\ Uniwersytet Warszawski \\ ORCID: 0000-0003-4362-9426; e-mail: janusz.siatkowski@wp.pl
}

\title{
Niezabudka, wasilek, wołoszka - o dylematach w rozstrzyganiu pożyczek i reliktów dawnej wspólnoty na pograniczu polsko-wschodniosłowiańskim
}

\begin{abstract}
Abstrakt: Na podstawie nazw kwiatów - niezabudka 'niezapominajka' i wasilek, wołoszka 'chaber' podjęto próbę rozstrzygnięcia problemu metodologicznego, jak traktować niektóre wyrazy gwarowe występujące na pograniczu polsko-wschodniosłowiańskim. Autorzy starają się odpowiedzieć na pytanie, czy wybrane jednostki leksykalne interpretować z punktu widzenia zapożyczeń, czy też uznawać je za kontynuacje dawnej wspólnoty słowiańskiej.

Jednoznaczne rozstrzygnięcie tego zagadnienia wymaga bardzo szczegółowych, wręcz drobiazgowych dociekań i ekscerpcji różnych źródeł - począwszy od słowników historycznojęzykowych przez monografie gwarowe, po publikacje z zakresu geografii językowej. Przedstawione nazwy na ogół pojawiają się dość sporadycznie w polskich gwarach na pograniczu wschodnim. Wydaje się, że trzeba tu przyjąć oddziaływanie również wschodniosłowiańskich języków literackich.
\end{abstract}

Słowa kluczowe: leksyka gwarowa, kontakty językowe, geografia lingwistyczna, zapożyczenia językowe, dialektologia słowiańska.

\begin{abstract}
Niezabudka, wasilek, woloszka: on the dilemmas of resolving borrowings and relicts of an earlier community in the Polish-East Slavic Borderland. Names of flowers such as niezabudka 'forget-me-not' and wasilek, wołoszka 'cornflower' are helpful in resolving a methodological problem of how to treat some subdialectal words used in the Polish-East Slavic Borderland. The author attempts to resolve whether the selected lexical items should be interpreted as lexical borrowings or as continuations of an earlier Slavic community.

An unambiguous resolution of this issue requires very detailed, meticulous research and excerption of various sources, ranging from dictionaries of language history through subdialect monographs to publications on linguistic geography. The above names are generally infrequent in Polish subdialects spoken in the Eastern Borderlands. It seems that the influence of the Eastern Slavic literary languages should also be taken into account.
\end{abstract}

Keywords: subdialect lexis, language contact, linguistic geography, lexical borrowing, Slavic dialectology.

Pogranicze polsko-wschodniosłowiańskie to obszar, na którym w ciągu kilku wieków dochodziło do kontaktów różnych języków, zarówno należących do rodziny 
słowiańskiej, jak i języka litewskiego, co wynikało m.in. z funkcjonowania w jednym organizmie państwowym. Język polski, ukraiński i białoruski silnie na siebie oddziaływały, a rezultaty tych wpływów były nierzadko trudne do przewidzenia i ujęcia w jednolity schemat. Prowadząc dociekania nad proweniencją niektórych wyrazów występujących na wskazanym pograniczu, badacz nierzadko ma niełatwy do rozstrzygnięcia problem metodologiczny, jak traktować te jednostki leksykalne - interpretować z punktu widzenia zapożyczeń czy też uznawać je za residua dawnej wspólnoty słowiańskiej. Zagadnienie to omawiamy na przykładzie nazw dwóch kwiatów - 'niezapominajki' i 'chabra'.

\section{Niezabudka 'niezapominajka'}

O wyrazie tym pisano już dużo. Po opracowaniach Sawaniewskiej-Mochowej (1990, 124), Waniakowej (2006a, 71-79; 2006b, 527-534; 2012, 111-112; 2015, 205-216) i Kosteckiej-Sadowej (2015, 330-331) wiadomo, że polska niezabudka stanowi pożyczkę z języków wschodniosłowiańskich. Do opracowań tych należy jednak wprowadzić kilka uzupełnień i uściśleń, a także wnieść pewne sprostowania, zwłaszcza w uporczywie powtarzanych błędnych informacjach o zasięgu tej pożyczki w gwarach polskich.

O zasięgu tej nazwy w gwarach słowiańskich daje dobrą informację OLA III (132-133), na mapie 53 Незабудка (Myosotis). Otóż podany w postaci uogólnionej leksem *ne-za-bod-rk-a, wraz z właściwym głównie dialektom ukraińskim wariantem *ne-za-bod-bk-a, tworzy obszerny areał w dialektach wschodniosłowiańskich i słowackich, z którym łączą się dwa punkty na polskim pograniczu wschodnim (Trzebieszów pod Łukowem i Choroszczynka pod Białą Podlaską). Poza tym zanotowano go w kilku punktach na zachodzie Polski od przesiedleńców spod Wilna, Lwowa i z Podola, a zatem należy je lokalizować w polskich dialektach kresowych. Wendina traktuje je podobnie (Вендина 2014, 94), ale na s. 378 swojej monografii niesłusznie mówi o izoglosie rusko-polskiej, zamiast rusko-słowackiej.

W dialektach słowackich to nazwa niewątpliwie rodzima. W OLA jest poświadczona powszechnie w dialektach środkowej i zachodniej Słowacji, występuje też na wschodzie, gdzie częściowo przeważa $* z ̌ a b-b j-E$ oč-bk-o. Podobny zasięg nazwy nezábudka, nezabútka 'niezapominajka' potwierdza również SSN II (429), a w słowackim języku literackim ma poświadczenia od XIX wieku (Králik 2015, 38; SSJ II, 370). Pod wpływem słowackim nezabudka pojawia się również w języku czeskim (Jungmann 1835-1839, II, 717; Kott 1878-1893, II, 162, VI 1189), dziś jest tu przestarzała (PS III, 558, SSJČ II, 198), ale sporadycznie została zapisana w gwarze na Morawach (ČJA II, 268-270, m. 113).

Materiały spoza OLA pokazują, że postaci sprowadzające się do uogólnionego zapisu *ne-za-bod-ъk-a mają na polskim pograniczu wschodnim znacznie szerszy zasięg, ale ich postać fonetyczna $\mathrm{z}$ samogłoską $u$, zamiast oczekiwanego kontynuantu samogłoski nosowej, wskazuje, że nie mamy tu do czynienia z dawną łącznością rusko-polską, lecz z pożyczką wschodniosłowiańską. 
Nazwę niezabudka 'niezapominajka' zamieszcza SGPK III (320) jako zasłyszaną na Litwie (ustnie z Litwy). Z Wileńszczyzny potwierdza ją Karłowicz (1984, 52). Z gwar polskich na Brasławszczyźnie Rieger $(2014,171)$ podaje ńezabútka jako imię krowy. Warto dodać, że ńezabútka odnoszącą się do nazwania krowy zanotowano też w polskich gwarach na Białorusi pod Lidą (PolGov, II, 170). Według Smułkowej (2009, 168) na Brasławszczyźnie w wypowiedziach traktowanych jako polskie występują ńezapom'inajki $i$, natomiast w białoruskich ńezabutki. Mamy też kilka poświadczeń tego wyrazu z polskich gwar kresowych: do wspomnianych już w OLA trzech punktów z przesiedleńcami spod Wilna, Lwowa i Podola można dodać zapisy ńezabutka 'niezapominajka' od przesiedleńców spod Lwowa - z Siemianówki i Wołostkowa (Lwów 2015, 165, nr 1294) oraz z Kozłowa pod Tarnopolem (Tarnopol 2007, 188, nr 1294), na co zwraca uwagę też Rieger $(2007,16)$. U przesiedleńców spod Nowogródka występuje niezabudek (Lewaszkiewicz 2017, 418), ale autor w thumaczeniu tego wyrazu użył synonimów 'niezabudka, niezapominajka', co świadczy, że sam też używa formy niezabudka).

Niezabudka znana jest w gwarach niemal całego Mazowsza. Pokazuje to mapa w atlasie mazowieckim. Na zachodzie sięga ona po skrajne punkty: Ostrowy pod Kutnem, Sierakówek pod Gostyninem, Gozdowo, Ligówko i Babiec Piaseczny pod Sierpcem oraz Chrapoń i Jasiony pod Żurominem. Niezapominajki notowano tylko w rozproszeniu, częste są natomiast żabie oczka i podobne (AGM, V, 146, m. 235). Brak tej nazwy tylko w najbliższych okolicach Warszawy, co obrazowo pokazuje płaszczyznowa mapa u Waniakowej (2006a, 79). Na mapie tej nie pojawiają się dane między wschodnią granicą Mazowsza a wschodnią granicą Polski. Mamy tu zbyt skąpe materiały, by stwierdzić, czy tu powszechniej występuje niezabudka. Jej brak na terenach przygranicznych może przemawiać za tym, że na Mazowsze dostała się ona nie z sąsiadujących gwar ruskich, lecz za pośrednictwem polskiego języka literackiego.

Z OLA, jak wspomniano, można podać Choroszczynkę pod Białą Podlaską oraz Trzebieszów pod Łukowem. Poza tym w kartotece SGP jest niezabudka w Siennicy Różanej pod Krasnymstawem bezpośrednio nawiązująca do szerszego areału w słowniku Pelcowej (2015, 318, m. 34). Notuje ona tu niezabudke w Dorohuczy i Trawnikach w pow. świdnickim, w Krzczonowie koło Bychawy oraz wokół Hrubieszowa w Skryhyczynie w gm. Dubienko nad samą granicą polsko-ukraińską, w Stefankowicach, Moniatyczach, Kopyłowie, Orłowcu i Jarosławcu. Na Lubelszczyźnie dominuje jednak niezapominajka, częste są też żabie oczka. Należy jeszcze dodać z kartoteki SGP niezabudkę z odległej miejscowości Książnice Wielkie koło Kazimierzy Wielkiej w Małopolsce. Niezabudkę 'niezapominajkę' zapisano także w Mościskach na Ukrainie tuż przy granicy polskiej koło Przemyśla (Kostecka-Sadowa 2008, 191). Takie rozproszenie może świadczyć o dawniej szerszym zasięgu niezabudki w gwarach polskich.

W dotychczasowych opracowaniach podawane są ponadto informacje o występowaniu niezabudki w okolicach Poznania i na Kaszubach (AGM, V, 146; Waniakowa 2012, 112; Kostecka-Sadowa 2015, 330-331). W naszych rozważaniach koncentrujących się na zasadności przyjmowania wpływu wschodniosłowiańskiego, w tym argumentu geograficznego o występowaniu tych pożyczek na ograniczonym obszarze wschodniego pogranicza, sprawa ta wymaga szczegółowego wyjaśnienia.

Lokalizacja pod Poznaniem opiera się na powołaniu na fiszkę kartoteki SGP dotyczącą Łopienna pod Wągrowcem w pracy Adama Tomaszewskiego, Gwara Łopienna 
i okolicy w pólnocnej Wielkopolsce (Kraków 1930). Na kartce tej umieszczono tylko przekreślone zero. Powinno to wzbudzić wątpliwości, zresztą Sawaniewska-Mochowa korzystająca również z tej kartoteki owej lokalizacji nie wymienia. Otóż autor na s. 217 umieszcza leksem niezabudka w osobnym zestawieniu ,garść wyrazów nieużywanych w naszej gwarze", co świadczy tylko o tym, że był on znany autorowi pracy jako regionalizm zasługujący na informację. Lokalizację tę trzeba więc wykreślić.

Warto też wyjaśnić umieszczenie niezabudki na terenie Kaszub. Przywoływany słownik Sychty (1967-1976, III, 252) ma tylko odsyłacz ńezabudka zob. ńezabåčka, a pod tym hasłem już o niezabudce nie wspomina. Warto dodać, że Hinze uzupełniający pierwotne zbiory Lorentza znalazł jednak formę ńezabundka w rękopiśmiennym zbiorze kaszubskich nazw roślin Leona Roppela (Lorentz 1958-1983, IV, 1592). Świadczy to tylko o powszechnej znajomości tego poetyzmu romantycznego w polskim języku ogólnym, nie wyłączając terenu Kaszub, ale do gwary kaszubskiej on jednak nie wszedł. Zresztą pod jego wpływem, jak słusznie zakłada Waniakowa (2015, 208), powstały neologizmy kaszubskie, jak ńezabåčka, ńezabåčnik, ńezabåtka (por. Sychta 1967-1976, III, 252).

Należy więc pozostać przy stwierdzeniu, że zapożyczona niezabudka weszła tylko do gwar wschodniej Polski oraz do polskich gwar kresowych. Inne poświadczenia dowodzą tylko jej ekspansji w ramach polskiego słownictwa literackiego (por. Waniakowa 2006a).

Niezabudka 'niezapominajka' ma dosyć bogate poświadczenie w literaturze. Wcześniej pojawiają się formy fonetycznie ruskie od dawnego zabyć 'zapomnieć', zabywać 'zapominać', występującego w staropolszczyźnie (Linde 1951, VI, 714) i notowanego jeszcze jako dawne przez SJPD $(X, 428)$ z przykładami z XIX wieku, a w gwarach zachowanego na Śląsku Cieszyńskim (kartoteka SGP) oraz na Kaszubach (por. zabëc 'zapomnieć' u Sychty [1967-1976, I, 27-29] s.v. bëc 'być'). Edward Redliński w Konopielce użył zwrotu ,zabyło sie na śmierć” (s. 54). Już Michał Dudziński $(1776,32)$ uważał zabyć, zabywać 'zapomnieć, zapominać' za słowo ruskie.

Jako formy fonetycznie ruskie zostały zanotowane w kartotece SXVII-XVIII W znaczeniu 'upominek, pamiątka' z Pamiętników (1666-1721) Krzysztofa Zawiszy: „Synek mój miły Józef wielą chorob zdjęty umarł, zostawiwszy pozostałym rodzicom w niezabud łzy i żal nieznośny”, i z rękopisu XVII/XWIII w. Historii świeżych i niezwyczajnych: „y mały iego portrecik, ktory jey na ne zabudesz darował”. Linde (1951, III, 342-343) przytacza z Wacława Potockiego (1728): ,już niesie i pierścionek, na krótki niezabudesz, przyszły twój małżonek", z Nauki cyrylickiej (1792) Ludwika Perzyny: „Francowate dymienice na niezabud od osob już zarażonych amanci odbierają”, i jeszcze z końca XVIII wieku: „Pani moja...prosi go, abyś jej odesłał portret jej i listy i niezabud wszelki” oraz: „Na wieczny niezabudesz konia ci mego ofiaruję”.

Notują te wyrazy i późniejsze słowniki: SWil (I, 778) jako potoczny prowincjonalizm podaje niezabud 'upominek, pamiątka', SW (III, 373) ma jako przestarzałe niezabud i przytacza znane już przykłady z Perzyny i Lindego, niezabudesz z cytatami z Potockiego i Lindego oraz niezabudysz: „Wezyr kamieniecki miał sobie przyrzeczoną niewielka sumę na niezabudysz", powołując się na Antoniego Rollego. Jako regionalne i dawne ma jeszcze SJPD (V, 285-286) niezabud 'upominek, pamiątka' z przytoczeniami z Henryka Rzewuskiego (1791-1866): „Chciałem dobyć szabli i byłbym mu dał 
taki niezabud...”, i Pauliny Wilkońskiej (1815-1875): „Panna Halina śle wam mały niezabud".

Wchodząca do języka polskiego niezabudka miała więc oparcie we wcześniejszych pożyczkach współrdzennych. Pojawia się ona późno. Linde (1951, III, 342-343) podaje niezabudki 'niezapominajki' bez lokalizacji i cytatu; SWil (I, 778) uważa niezabudke za pospolitą nazwę występującą u ludu na Litwie; SW (III, 373), uznając ją za pożyczkę z ukraińskiego, poświadcza przykładami z Adama Mickiewicza i Juliusza Słowackiego.

U Słowackiego jest to wyraz bardzo częsty, choć ma on także wyrazy niezapominka i niezapominajka. Używa go wielokrotnie, zarówno w postaci fonetycznie niespolonizowanej, jak i w spolonizowanej (por. Jurkowski 1974, 122). Postać nezabudka występuje w Beniowskim: „z nezabudka, Rozmawia czyściej lilia”, i we Śnie srebrnym Salomei: „Jak na małą nezabudkę Księżniczka patrzy z wysoka”. Częstsza jest forma spolonizowana niezabudka, pojawiająca się w Beniowskim: „Jak niezabudka drżąca przy leszczynie”, „Ja, co kwiaty koszę w niezabudkowej przeszłości murawie”, w Balladynie: „Jako niezabudki”, i w wierszu Księżyc: „Niezabudki, bławatki, lilije, tymianki”. Z Mickiewicza podawany jest werset z powieści poetyckiej Konrad Wallenrod: „Chciałbym jeden mały kwiat uszczknąć, kwiat niezabudki”. Jak słusznie twierdzi Bešta $(1971,211)$, jest to romantyczny poetyzm wzięty z języka ludowego, który wszedł do języka literackiego. Za regionalizm uważa niezabudkę SJPD (V, 285-286), cytując utwory Juliusza Słowackiego, Zygmunta Krasińskiego, Pauliny Wilkowskiej, Elizy Orzeszkowej, Zofii Kossak-Szczuckiej, Antoniego Słonimskiego i Adama Asnyka. Niezabudka to również tytułowa nazwa wiersza dla dzieci Marii Konopnickiej, urodzonej w Suwałkach.

W latach 1840-1844 ukazywało się w Petersburgu czasopismo literackie „Niezabudka. Noworocznik" wydawane przez Jana Barszczewskiego. W pierwszym numerze (1840 r.) zamieszczono wiersz Dumka Wincentego Dawida (1816-1897, urodzonego w Szczebrzeszynie), w którym pojawia się nazwa omawianego kwiatu: „A ja zerwę niezabudkę / Niezabudkę tę malutkę / Jej to kwiatek ulubiony, / Pójdź kwiateczku w obce strony" (s. 3).

We współczesnej polszczyźnie wyraz niezabudka funkcjonuje w obiegu także w warstwie proprialnej, jako nazwa obiektów mieszkalnych (np. Willa „Niezabudka” w Nałęczowie) i lokali użytkowych (np. „Niezabudka” Studio Urody w Poznaniu), element składowy nazw instytucji usługowo-opiekuńczych (np. Ośrodek Rehabilitacyjno-Edukacyjno-Wychowawczy „Niezabudka” w Kutnie). Jak widać, geografia tych nazw własnych nie wiąże się z zasięgiem apelatywu.

Skomplikowane międzysłowiańskie związki językowe w nazwach niezapominajki właściwie ustala Waniakowa, autorka kilku obszernych opracowań (2006a, 71-79; 2006b, 527-534; 2012, 111-112; 2015, 205-216) o nawach tej rośliny w kontekście języków Europy. Nazwy takie, jak niezapominajka, niezabudka itp., stanowią kalkę niem. Vergißmeinnicht, która do języków wschodniosłowiańskich dostała się bezpośrednio lub raczej za pośrednictwem języka polskiego, a po naszych ustaleniach można tu dodać jako język pośrednik także słowacki. Kalka ta w postaci niezabudka wróciła do nas jako pożyczka zwrotna z ukraińskiego. 
Wasilek, wasilka i woloszka 'chaber, Centaurea cyanus L.'

Polskie gwarowe nazwy chabra bławatka 'Centaurea cyanus L.' na tle słowiańskim i europejskim przedstawiła Waniakowa (2019, 173-187). Wśród nich są dwie nazwy wasilek, wasilka i wołoszka, które zostały zapożyczone z języków wschodniosłowiańskich. Na wpływ ten zwrócono uwagę już wcześniej (por. Nitsch 1954-1958, II, 9697; Hrabec 1949, 46-47, 114, 133; Sawaniewska-Mochowa 1990, 134; Kurzowa 1993, 445-446, 449; Pastusiak 2007, 149-151; Kostecka-Sadowa 2015, 339, 340; Сабадош 2015,379 i in.).

Nazwa wołoszka jest motywowana włochatym wyglądem kwiatów i owłosionych łodyg rośliny (Waniakowa 2019, 179) lub wiąże się z dawną nazwą ludów romańskich волох, валах (por. Фасмер 1964-1973, I, 345, ESBM, II, 43-44, Сабадош 2015, 21). Na pożyczkę z języków wschodniosłowiańskich jasno wskazuje jej postać z pełnogłosem.

Już staropolską nazwę wasilek oznaczającą różne rośliny, ale nie 'chaber', za powstałą pod wpływem ruskim uznaje Karpluk $(1988,153)$, choć podobnie jak imię $W a-$

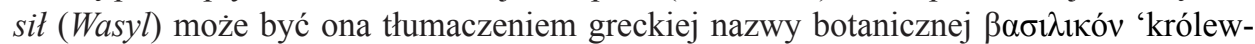
skie'. Należy też zwrócić uwagę, że imię Wasyl, uważane za ruskie, w XIV-XV wieku dosyć powszechnie występowało w języku polskim, nawet w Małopolsce i Wielkopolsce (SSNO, VI, 27-28), a mogło być też użyte, jak zakłada Hrabec (1949, 32), jako nazwa pospolita w znaczeniu 'chłop ruski', np. w Zwierzyńcu Mikołaja Reja: „Ów też zasię drugi, co sie tylko na grzegorze albo wasiłki rozmyślał [...] tam też sprawa trudna ma być". Późniejszy wasilek 'chaber' powszechnie uznaje się za pożyczkę ruską (por. wyżej). Nazwa ta eksponuje początek kwitnienia chabra około dnia św. Bazylego (25 maja). Jest też ludowe tłumaczenie powstania nazwy wasilek 'chaber' związane z ukraińską legendą, że miał on wyrosnąć na mogile załaskotanego na śmierć przez rusałki chłopca o imieniu Wasyl (SSiSL, II, 74).

Pożyczki te chcemy przedstawić nieco dokładniej, zwracając większą uwagę na ich zasięgi gwarowe znane $\mathrm{z}$ kilku opracowań atlasowych i na nasuwające się w związku z tym wnioski. Prostujemy też kilka powtarzanych błędów.

$\mathrm{Na}$ mapie OLA (IV, 61) nazwy te sąsiadują ze sobą. Nazwa *vasilbkъ zajmuje tu obszerny zwarty areał, obejmujący gwary rosyjskie oraz północno-wschodnią Białoruś. Poza tym *vasilbkъ w rozproszeniu pojawia się na całej niemal Ukrainie (васил'óк, вас'іл'о́к lub pl. васи́л'ки, васил'ки́, m.in. na Zakarpaciu: Сабадош 1999, m. 10), sporadycznie na pograniczu z Białorusią w miejscowości Tur (Typ) niezbyt daleko od granicy polskiej, a poza tym na Białorusi m.in. w miejscowości Dmitrowicze (Дзмітравічы) blisko Białowieży po polskiej stronie. Na zachodniej Ukrainie rzadko występują też *vasilbky w miejscowości Sieczy (Сечы) na północ od Brześcia i w miejscowości Przewałka (Прывалкі) na północ od Grodna oraz w Łosku (Лоск) w rejonie wołożyńskim, *vasilbka we wsi Bojary Wielkie (Вялікія Баяры) koło Szczuczyna, w Poleckiszkach (Паляцкішкі) nad granicą litewską (koło Solecznik po drugiej stronie granicy) i w miejscowości Łuksze (Лукшы) na północ od Brasławia, a poza tym * vasilъka w Polsce w Radziuszkach pod Sejnami.

W południowo-zachodniej Białorusi oraz na całej niemal Ukrainie występuje *volšbka (воло́шка i pl. воло́шкu), ale na Ukrainie wzdłuż granicy z Polską dosyć znaczny 
obszar zajmuje przejęty z gwar polskich *blavatъ (вла́ваm pl. влава́ти, por. Сабадош 1999, m. 10). Polski bławat, bławatek 'chaber' zaś stanowi derywat od stpol. przymiotnika bławy 'niebieski' wywodzącego się ze śrwniem. blā, blaver (por. Waniakowa 2019, 174-175).

Dalsze atlasy wprowadzają tu znaczne uściślenia. W atlasie białoruskim (LAB, I, 97, m. 229) przy podobnym podziale geograficznym na północno-wschodni васілёк (i ва́сілька, васі́лька) i południowo-zachodnią вало́шка mamy znacznie częstsze niż w OLA poświadczenia nazwy васілёк w zwartym areale nazwy вало́шка oraz w zachodniej Białorusi, a mianowicie васілёк w trzech punktach na północ od Brześcia: Raśna (Расна) koło Kamieńca, podawane przez OLA Dmitrowicze (Дзмітравічы) i Kamieniuki (Камянюкі); w kilku punktach w okolicy Grodna: na południe w miejscowościach Korobczyce (Каробчыцы) i Strzelce (Стральцы), na północ we wspomnianej już w OLA wsi Przewałki (Прывалкі) oraz pod Szczuczynem we wsiach Berszty (Бершты) i Кościeniewo (Касцянева), a dalej na północ szerokim pasem wzdłuż granicy litewskiej i łotewskiej васілёк, ва́сілька і васі́лька.

Tarnacki (1939, 61, m. 149) stwierdza, że na Polesiu zachodnim ogólnopoleska nazwa wołoszka ustępuje w powiecie bielskim przed mazowieckim chabrem, a w powiecie kowelskim przed małopolskim bławatkiem. Kilka opracowań gwarowych, przytaczanych przez autorkę komentarza do AGWB (VIII, 212-215) Kazimierę Pastusiak, podających lokalizację nazwy валóшка, pokazanego jej zasięgu w LAB nie rozszerza. Słownik pogranicza SPZB (I, 277) ma tylko nazwę валóшка: z dwóch miejscowości mieszczących się w areale wyznaczonym przez LAB oraz ze wsi Knyszewicze leżącej na południe od Sokółki na Białostocczyźnie.

Również w gwarach wschodniosłowiańskich w tym regionie zanotowano tylko nazwę вало́шка. Występuje ona tu w szerokim pasie przygranicznym od Biebrzy po Hajnówkę, sięgając w części centralnej aż po Białystok. Ciekawe, że postać vałłoška nie przekracza tu granicy akania (AGWB, I, m. 1), a w okolicy Białegostoku, gdzie akania nie ma, zapisano volloška (AGWB, VIII, 212-215, m. 368). W zachodniej Białostocczyźnie zapewne pierwotna tu vał́oška, voł́oška, została wyparta przez derywaty (ze zmianą rodzajową na rodzaj żeński) wywodzące się od polskiej nazwy chaber ( $\chi^{\prime} a b e r$

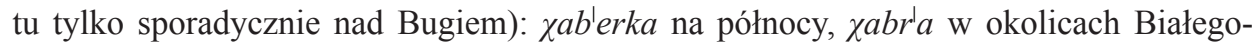

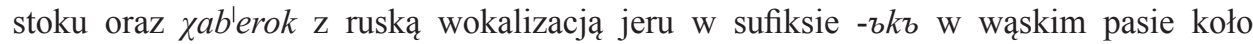

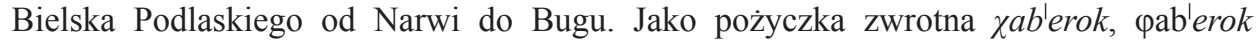
pojawia się pod Bielskiem Podlaskim w wypowiedziach, które można traktować jako polskie (Tarnacki 1939, 61; Waniakowa 2019, 180).

Zasięgi geograficzne sąsiadujących wyrazów *vasilbkъ i *vúšbka w gwarach słowiańskich wydają się wskazywać, że tworzący pierwotnie zwarty areał na terenie Rosji i północno-wschodniej Białorusi *vasilbkъ pojawił się w areale nazwy *vúšbka w rozproszeniu $\mathrm{w}$ gwarach ukraińskich i na terenie południowo-zachodniej Białorusi pod wpływem rosyjskiej i białoruskiej postaci literackiej.

Białoruski literacki васілёк 'chaber, Centaurea cyanus L.' notuje dopiero słownik języka współczesnego TSBM (I, 468), ale jako literacka podawana jest również вало́шка (TSBM, I, 458).

Ukraińskie василки notowane są od połowy XVII wieku, głównie jednak w znaczeniu 'bazylia, Ocynum Basilicum' (SUM XVI-XVII, III, 184). Hrinčenko 
(Грінченко 1907-1909, I, 128) родаjе васи́льóк na oznaczenie pięciu różnych roślin, ale nie chabru. Dopiero słownik współczesny SUM (I, 296), zapewne pod wpływem rosyjskim, ma васи́льк. W znaczeniu 'chaber', ale też 'bazylia'. Leksem stał się chyba jednak na Ukrainie dosyć powszechny, skoro wszedł do utworów pisarzy polskich związanych z kresami południowymi. Utożsamienie wasilka 'chabru' z bazylia wiąże się zapewne z tym, że w antroponimii wschodniosłowiańskiej (i słowackiej) imię Wasyl, Wasyli jest jednoznaczne z Bazylim. Nazwę волóшка z kolei jako określenie 'chabru' notuje Hrinčenko (Грінченко 1907-1909, I, 252-253), a także SUM (I, 734).

W języku rosyjskim василекъ notowany jest od XVII w., ale trudno określić jego znaczenie: redaktorzy jako ekwiwalent współczesny dają 'василек', jednak jeden z cytatów „По-руски василки [...] базиликон” świadczy, że raczej chodzi o bazylię (SRJ XI-XVII, II, 23), w XVIII wieku василек oprócz wielu innych roślin nazywa też 'chabra' (SRJ XVIII). Również u Dala василе́къ odnosi się do wielu różnych roślin, m.in. do 'bazylii', ma jednak również znaczenie 'chaber'(Даль 1955-1956, I, 167). Słownik języka współczesnego SSRLJ (I, 58) daje василёк już tylko w znaczeniu 'chaber'. Nazwę chabra воло́шка notuje SRJ XVIII, a Dal podaje ją jako regionalną, południową (Даль 1955-1956, I, 237; ciekawe, że wśród synonimów wymienia również pożyczkę polską блавámка).

Omawiane wyrazy jako pożyczki z języków wschodniosłowiańskich mają dosyć bogatą dokumentację w języku polskim. Wchodzi tu w grę ich przejmowanie do gwar polskich bezpośrednio z sąsiadujących gwar białoruskich i ukraińskich, jak i - zwłaszcza - wpływy wschodniosłowiańskich języków literackich.

Wyraz wasilek notuje już Słownik staropolski na oznaczenie kilku nazw roślin, m.in. 'bazylii', ale nie jako nazwę 'chabru' (SStp, X, 47) $)^{1}$. Hrabec $(1949,114)$ podaje z Sielanek (1663) Bartłomieja (nie Szymona, jak podaje Kostecka-Sadowa 2015) Zimorowicza dwa cytaty z wasilkiem/wasitkiem oznaczającym 'chaber': „Zwiesi wieniec, z wasiłku uwity równym kołem” i „Kędy tylko wasilek kocha się i mięta, Jako sama dziewice urodą przoduje, Tak przy niej insze zioła wasiłek celuje".

Za SW (VII, 471) przytaczany jest poza tym (Kurzowa 1993, Kostecka-Sadowa 2015) polegający na nieporozumieniu przykład z Sebastiana Klonowica: „Nie o wasieł$k i$, ziarno miej na pieczy, Nad inne rzeczy". Jak wyjaśniono zresztą w przypisie do wydania utworu Klonowica, chodzi tu o wyraz wasitka w znaczeniu 'towar leśny, deseczka służąca do wyrobu klepek'. Dotyczy to też podawanego przez Kurzową drugiego źródła - Instruktarza celnego litewskiego.

Można za Kurzową (1993) podać natomiast z Ignacego Chodźki: „skromne wasilki i wonne cząbry". Według jej informatorów wasilka w znaczeniu 'chaber' była znana w polszczyźnie wileńskiej w okresie międzywojennym. Poza tym znajomość nazwy wasilek 'chaber' na Wileńszczyźnie potwierdzają Karłowicz (1984, 70), Walicki (1886,

\footnotetext{
${ }^{1}$ O nierozróżnianiu dwóch różnych roślin o tej samej nazwie świadczy chociażby komentarz autorki w artykule z ubiegłorocznego numeru „Przekroju” o bazylii: „w Dekameronie Giovanniego Boccaccia [bazylia] patronuje tragicznej historii miłosnej w stylu włoskiego południa. [...] w polskim przekładzie Edwarda Boyégo oryginalną bazylię z Salerno wyparły, nie wiedzieć czemu, wasilki, czyli chabry bławatki, co jest dość irytujące, bo przecież bazylia to bazylia, a chaber to chaber. Tym bardziej że chaber nie ma w tej ociekającej sycylijskim temperamentem noweli żadnego sensu” (Lis 2019, 86).
} 
416), Łętowski (1915, 323), Turska (1982, 73, 80 - wasilek i wasilka f.). W Zielniku ekonomiczno-technicznym, wydanym w Wilnie, pod hasłem chaber, bławatek Centaurea Cyanus znajduje się adnotacja „posp. wasilek” (Wyżycki 1845, 247). Ponadto z polszczyzny gwarowej na Litwie Zdaniukiewicz (1972, 215) z Łopatowszczyzny koło Turgiel nad granicą białoruską rejestruje: wasilek (vas'il'ak, vaślilek), a Rieger, Masojć, Rutkowska (2006, 411) na znacznym obszarze Litwy: wasilek z Wierszuliszek i Świętnik na północ od Wilna, wasilka z Dojlid na południu, spod Landwarowa koło Wilna i ze Smołw na północy, wasiłka z miejscowości Imbrody na północy, Widugiry pod Święcianami i Ragoże pod Kownem oraz wasilok w okolicy Landwarowa. Dalsze lokalizacje z Wileńszczyzny podaje SMPP (1226).

Również na sąsiadującej z Wileńszczyzną Brasławszczyźnie w dialektach polskich notowano vaśil'ek, vas "iłka, vas "iłk'i obok częstszej nazwy bławatek, bławatk'i, natomiast w wypowiedziach traktowanych jako białoruskie tylko vas "il'ok, v'as "itk'i, vas " il' $k$ ' $i$ (Brasławszczyzna, 166; Rieger 2014, 278). Wasilek 'chaber' zauważono też u ludności polskiej na Białorusi sowieckiej (Dombroski 1932, 263; por. SMPP, 1226 oraz wasitki 'chabry' u przesiedleńców z Kresów Północno-Wschodnich pod Bartoszycami: Sawaniewska-Mochowa 1982, 74).

W gwarach polskich na obecnym pograniczu wschodnim wasilek, wasilka jako nazwy 'chabru' pojawiają się tylko sporadycznie. Osipowicz $(2009,121)$ podaje z XIX-wiecznej gwary augustowskiej wasilki 'bławatki, modraki, chabry', natomiast w kartotece SGP mamy jeszcze tylko ze Sławatycz pod Włodawą vasilki określane jako 'gatunek kwiatów łąkowych', a Pelcowa (2001, 57 i m. 34) z dwóch punktów na północ od Włodawy podaje wasylki w znaczeniu 'ostróżka polna, Delphinium consolida', natomiast na mapach 'chabru' ani u Czyżewskiego (1986b, m. 20), ani u Pelcowej (2001, m. 30) spod Włodawy i z całej Lubelszczyzny nazwy tej nie odnotowano, dominują tu natomiast właściwe gwarom polskim chaber i bławat.

Należy jeszcze dodać, że wasilek 'chaber', przytaczany w opracowaniach chabru bławatka (już Sawaniewska-Mochowa 1990, 134, też Kostecka-Sadowa 2015) z miejscowości Huszcza pod Białą Podlaską, polega na nieporozumieniu. W kartotece SGP na fiszce z tej miejscowości z hasłem wasilki jest tylko przekreślone $\varnothing$, oznaczające, że eksplorator uznał za wskazane, by poinformować, iż nazwa ta w Huszczy nie jest znana. Osoby związane z pracownią SGP powinny to wiedzieć lepiej niż my. Brak tej nazwy w Huszczy wpisuje się zresztą w sygnalizowaną przez nas ekspansję nazw polskich zarówno na Lubelszczyźnie, jak i w gwarach wschodniosłowiańskich na Białostocczyźnie.

Nazwę wołoszka 'chaber' odnotowano na pograniczu polsko-litewskim (Гюлумянц 1982, 226; por. SMPP, 1264). W brzmieniu wałoszka, wołoszka jest dosyć częsta na pograniczu wschodnim. W AGP (II, m. 159) podano formę wałaszka (błędnie uogólnioną zamiast wałoszka) z rozległego zwartego obszaru ograniczonego od zachodu przez miejscowości Przerośl i Okuniowiec koło Suwałk, Szczebra i Solistówka pod Augustowem, Szymany koło Grajewa, Osowiec i Milewskie koło Moniek, Krynki koło Sokółki i Ciwoniuki, gmina Michałowo na południowy wschód od Białegostoku, a wołoszka w niewielkim areale wzdłuż Bugu w powiecie bialskim we wsiach Kąty w gminie Kodeń, Matiaszówka w gminie Tuczna, Jabłeczna w gminie Sławatycze, Motwica 
w gminie Sosnówka i w powiecie włodawskim w miejscowości Hanna ${ }^{2}$. Przedstawiła je Pelcowa na czterech jednakowych mapach (Pelcowa 1985, 70, m. 2A [tu tylko 3 pierwsze punkty]; 1997, 199, m. IV; 2001, 136, m. 30; 2017, 492 i 539). Jednakże w leżącej nieco bardziej na zachód od tej wyspy miejscowości Huszcza w gminie Łomazy według kartoteki SGP nazwa ta już nie występuje. Kostecka-Sadowa (2015) podaje, jakoby wołoszka była znana jeszcze w powiecie radzyńskim i lubelskim, ale wynika to z błędnej lokalizacji miejscowości mających takie same nazwy bez sprawdzenia ich położenia na mapie Pelcowej.

Z przedstawioną wyspą łączy się wieś Dołhobrody w powiecie włodawskim, położona na południe od wspomnianej miejscowości Hanna (Czyżewski 1968a, 98; 1986b, m. 20). Sytuacja pod Włodawą jest szczególnie ciekawa. Dzięki pomysłowo dobranym na mapie znakom widzimy tu plastycznie wzajemne wpływy. Często nawet w tych samych punktach zapisano wypowiedź polską i ukraińską. Np. w trzech sąsiadujących ze sobą punktach nad górnym biegiem Zielawy obok polskiej nazwy zaber występuje zapożyczony z dialektów polskich ukraiński $\chi a b^{\prime}$ or. Przy częstych na północy powiatu ukraińskich nazwach volłoška, wułloška jako polska wołoška pojawia się tylko raz, częściej natomiast notowano tu polski bławat pojawiający się również w wypowiedziach ukraińskich jako błavat.

Wałoszki, wołoszki 'chabry' były znane również w Bohatyrowiczach nad Niemnem (Bohatyrowicze 1998: 201, 302). Kostecka-Sadowa (2008, 338; 2015, 340) podaje wołoszkę 'chaber' z Mościsk, leżących tuż za polską granicą koło Przemyśla: „W pšynicy nazrywała wołoszki i zróbiła śliczny wianuszek". Ma ona też kilka poświadczeń w polszczyźnie ogólnej. Kurzowa (1993) przytacza z Władysława Syrokomli: „Drobna jarzyna, wołoszka i ziele”. Znajomość leksemu w potocznej polszczyźnie wileńskiej potwierdza Walicki (1886, 416). Nazwę wołoszka w znaczeniu 'chaber' SWil (II, 1889) określa jako pospolitą, SW (VII, 694) uznaje ją za gwarową, a SJPD za dawną. Nie dokumentują jej żadnymi przykładami.

Według Waniakowej (2019) w przewodnikach dla zbieraczy ziół pojawia się też forma męska wołoszek w znaczeniu 'chaber'. Pelcowa (2015, 197-198, m. 9) w pasie nadgranicznym od Chełma aż nieco na północ od Włodawy oraz w odosobnionym punkcie na zachód od Białej Podlaskiej notuje współrdzenne derywaty wołoszek, wołoszun, wołoszuk oznaczające roślinę Phaseolus, podobną do grochu, o podłużnych ziarnkach, wijącą się na tyczkach, a także niską fasolę niepotrzebującą tyczek. Ze względu na formę z pełnogłosem są one także pożyczkami z języka ukraińskiego. Znalezienie ewentualnych wzorów ukraińskich wymagałoby specjalnych poszukiwań. U Hrinčenki i w SUM ich nie ma.

Jak pokazała nasza analiza, jednoznaczne rozstrzygnięcie, czy mamy do czynienia z pożyczką, czy z reliktem dawnej wspólnoty na pograniczu polsko-wschodniosłowiańskim, wymaga bardzo szczegółowych, wręcz drobiazgowych dociekań i ekscerpcji różnych źródeł - począwszy od słowników historycznojęzykowych przez monografie

${ }^{2}$ W gwarach polskich na Lubelszczyźnie notowano też przymiotnik wołochaty 'kosmaty, włosem porosły, z długimi włosami’ pod Międzyrzecem Podlaskim, w Łomazach na południe od Białej Podlaskiej, w miejscowości Wisznice na północy powiatu włodawskiego i we wsi Żdżanne pod Krasnymstawem, a niezależnie też w gwarze kresowej na Podolu (Czyżewski 1986a, 98). 
gwarowe, po publikacje z zakresu geografii językowej. Przedstawione nazwy na ogół pojawiają się dość sporadycznie w polskich gwarach na pograniczu wschodnim. Jak się zdaje, trzeba tu przyjąć oddziaływanie również wschodniosłowiańskich języków literackich.

\section{Literatura}

AGM, Atlas gwar mazowieckich, t. I, opr. H. Horodyska-Gadkowska, A. Strzyżewska-Zaremba, t. II-X, opr. A. Kowalska, A. Strzyżewska-Zaremba, Wrocław 1971-1992.

AGP, Atlas gwar polskich, t. I: Małopolska, K. Dejna, t. II: Mazowsze, K. Dejna, S. Gala, A. Zdaniukiewicz, F. Czyżewski, t. III: Śląsk, K. Dejna, S. Gala, t. IV: Wielkopolska, Kaszuby, K. Dejna, Warszawa 1998-2002.

AGWB, Atlas gwar wschodniostowiańskich Białostocczyzny, t. I, red. S. Glinka, A. Obrębska-Jabłońska, J. Siatkowski, t. II-III, red. S. Glinka, t. IV-X red. I. Maryniakowa, Wrocław Warszawa, 1980-2012.

Bešta T. (1971), Z badań nad wschodniostowiańskimi wptywami językowymi w polszczyźnie romantyków, „Rozprawy Komisji Językowej ŁTN”, XVII, s. 199-241.

Bohatyrowicze sto lat później, opr. I. Grek-Pabisowa, K. Handke, M. Ostrówka, A. Zielińska, Warszawa 1998.

Brasławszczyzna, Brasławszczyzna. Pamięć i współczesność, t. 2: Stownictwo dwujęzycznych mieszkańców rejonu (Stownik brasławski), red. E. Smułkowa, Warszawa 2009.

Brückner A. (1957), Stownik etymologiczny języka polskiego, Warszawa.

ČJA, Český jazykový atlas, red. J. Balhar, P. Jančák, sv. I-VI, Praha 1992-2011.

Czyżewski F. (1986a), Zapożyczenia ukraińskie w gwarach b. powiatu włodawskiego, „Studia nad polszczyzną kresową", t. IV, s. 81-107.

Czyżewski F. (1986b), Atlas gwar polskich i ukraińskich okolic Włodawy, Lublin.

Dombroski C. (1932), Ze słownictwa i gramatyki języka ludności polskiej na Białorusi sowieckiej, Mińsk.

Dudziński M. (1776), Zbiór rzeczy potrzebniejszych do wydoskonalenia języka, Wilno.

Hrabec S. (1949), Elementy kresowe w języku niektórych pisarzy polskich XVI i XVII wieku, Toruń.

Jungmann J. (1835-1839), Slovník česko-německý, sv. I-V, Praha.

Jurkowski M. (1974), Ukrainizmy w języku Juliusza Stowackiego, [w:] Z dziejów stosunków literackich polsko-ukraińskich, red. S. Kozak, M. Jakóbiec, Wrocław, s. 105-135.

Karłowicz J. (1984), Podręcznik czystej polszczyzny dla Litwinów i Petersburszczan, do druku przyg. E. Smułkowa, „Studia nad polszczyzną kresową”, t. III, s. 33-81.

Karpluk M. (1988), Kulturowo-antroponimiczne elementy w staropolskich nazwach ziót, [w:] V Ogólnopolska Konferencja Onomastyczna, Poznań 3-5 września. Księga referatów, red. K. Zierhoffer, Poznań, s. 147-156.

Kostecka-Sadowa A. (2008), Stownictwo gwar polskich w Mościskach i wsiach okolicznych, [w:] Stownictwo kresowe. Studia i materiaty, red. J. Rieger, Warszawa, s. 113-260.

Kostecka-Sadowa A. (2015), Rzeczownikowe zapożyczenia wschodniostowiańskie w gwarach polskich, Kraków. 
Kott F.Š. (1878-1893), Česko-německý slovnik, zvláště gramaticko-frazeologický, sv. I-VII, Praha.

Králik L. (2015), Stručný etymologický slovnik slovenčiny, Bratislava.

Kurzowa Z. (1993), Język polski Wileńszczyzny i Kresów pótnocno-wschodnich XVI-XX w., Warszawa - Kraków.

Lewaszkiewicz T. (2017), Język powojennych przesiedleńców z Nowogródka i okolicy, Poznań.

Linde S.B. (1951), Stownik języka polskiego, t. I-VI, wyd. 3. fotoofsetowe, Warszawa [pierwodruk: Lwów 1854-1860].

Lis R. (2019), Królewskie ziele, „Przekrój”, nr 3566, s. 86.

Lorentz F., (1958-1983), Pomoranisches Wörterbuch, fortgeführt von F. Hinze, Bd. I-V, Berlin.

Lwów 2015, Słownictwo gwarowe przesiedleńców z Ukrainy. Słownik porównawczy kilku wsi we Lwowskiem, z materiałów zebranych pod kier. W. Paryla, oprac. K. Czarnecka, D.A. Kowalska, E. Rudolf-Ziółkowska, red. K. Czarnecka, D.A. Kowalska, Kraków.

Łętowski A. (1915), Miłujmy język ojczysty. Błędy nasze. Rzecz o czystości języka polskiego na Litwie, Wilno.

Nitsch K. (1954-1958), Wybór pism polonistycznych, t. I-IV, Wrocław.

Osipowicz A. (2009), Słowniczek gwary augustowskiej, [w:] Dziewiętnastowieczne słowniczki gwarowe z Polski pólnocnowschodniej, red. B. Nowowiejski, Białystok, s. 7-130.

Pastusiak K. (2007), Pogranicze polsko-białorusko-ukraińskie w świetle danych językowych $i$ etnograficznych na podstawie nazw roślin, Warszawa.

Pelcowa H. (1985), Studia nad stownictwem gwarowym Lubelszczyzny, cz. I: Stownictwo pochodzenia małopolskiego, Lublin.

Pelcowa H. (1997), Stownictwo wschodniosłowiańskie w gwarach Polski środkowo-wschodniej $w$ świetle związów językowych polsko-ukrainskich, [w:] Ze studiów nad gwarami wschodniostowiańskimi w Polsce, red. F. Czyżewski, M. Łesiów, Rozprawy Slawistyczne, t. 12, Lublin, s. 189-211.

Pelcowa H. (2001), Interferencje leksykalne w gwarach Lubelszczyzny, Lublin.

Pelcowa H. (2015), Stownik gwar Lubelszczyzny, t. IV: Sad i ogród warzywny, budownictwo i przestrzeń podwórza, Lublin.

Pelcowa H., (2017) Stownik gwar Lubelszczyzny, t. V: Świat roślin, Lublin.

PS, Přiručni slovník jazyka českého, sv. I-VIII, Praha 1933-1957.

Rieger J. (2007), Dawne słownictwo przesiedleńców z Tarnopolszczyzny, [w:] Stownictwo przesiedleńców z Ukrainy. Stownik porównawczy kilku wsi w Tarnopolskiem, red. J. Rieger, Kraków, s. 11-20.

Rieger J. (2014), Stownictwo polszczyzny gwarowej na Brasławszczyźnie, Warszawa.

Rieger J., Masojć I., Rutkowska K. (2006), Słownictwo polszczyzny gwarowej na Litwie, Warszawa.

Sawaniewska-Mochowa Z. (1982), Osobliwości fonetyczne i fleksyjne dialektu pótnocnokresowego zachowane w mowie mieszkańców okolic Bartoszyc, Acta Universitatis Nicolai Copernici, Nauki Humanistyczno-Społeczne, Filologia Polska, t. XX, Torun, s. 65-83.

Sawaniewska-Mochowa Z. (1990), Poradnik Jana Karłowicza jako źródło poznania potocznej polszczyzny pótnocnokresowej. Słownictwo, Polono-Slavica Varsovinsia, t. 5, Warszawa. 
SGP, Słownik gwar polskich, opr. przez Zakład Dialektologii Polskiej Instytutu Języka Polskiego PAN w Krakowie, t. I, kier. M. Karaś, t. II-V, kier. J. Reichan, t. VI-VIII kier. J. Okoniowa, t. IX-, kier. R. Kucharzyk, Wrocław - Kraków, 1977-.

SGPK, Karłowicz J. (1900-1911), Słownik gwar polskich, t. I-VI, Kraków.

SJPD, Stownik jezzka polskiego, red. W. Doroszewski, t. I-XI, Warszawa 1958-1969.

SMPP, Słownik mówionej polszczyzny pótnocnokresowej, opr. I. Grek-Pabisowa, M. Ostrówka, M. Jankowiak, Warszawa 2017, https://ispan.waw.pl/ireteslaw/handle/20.500.12528/128, 12.01.2020.

SSiSL II, Stownik stereotypów i symboli ludowych, t. II: Rośliny, red. J. Bartmiński, S. Niebrzegowska-Bartmińska, Lublin 2019, s. 71-84.

SSJ, Slovník slovenského jazyka, red. Š. Peciar, sv. I-VI, Bratislava 1959-1968.

SSJČ, Slovnik spisovného jazyka českého, red. B. Havránek, t. I-IV, Praha 1960-1971.

SSN, Slovnik slovenských nárečí, red. I. Ripka, Bratislava 1994-.

SSNO, Stownik staropolskich nazw osobowych, red. W. Taszycki, t. I-VII, Wrocław 1950-1965.

SStp, Stownik staropolski, red. S. Urbańczyk, t. I-XI, Warszawa - Kraków 1953-2004.

SW, Stownik języka polskiego, (red.) J. Karłowicz, A. Kryński, W. Niedźwiedzki, t. I-VIII, Warszawa 1908-1927 [tzw. Stownik warszawski].

SWil, Stownik języka polskiego, wypr. przez A. Zdanowicza, M. Bohusza Szyszkę i in., t. I-II, Wilno 1861.

SXVII-XVIII, Kartoteka Słownika języka polskiego XVII i 1. połowy XVIII wieku, opr. Zakład Językoznawstwa PAN, Warszawa 1955-2011, https://rcin.org.pl/ijp/publication/20029, 15.10.2020.

Sychta B. (1967-1976), Słownik gwar kaszubskich na tle kultury ludowej, t. I-VII, Wrocław.

Tarnacki J. (1939), Studia porównawcze nad geografia wyrazów (Polesie - Mazowsze), Warszawa.

Tarnopol 2007, Stownictwo gwarowe przesiedleńców z Ukrainy. Stownik porównawczy kilku wsi $w$ Tarnopolskiem, z materiałów zebranych pod kier. W. Paryla, oprac. K. Czarnecka, D. Kowalska, E. Rudolf-Ziółkowska, red. J. Rieger, Kraków 2007.

Tomaszewski A. (1930), Gwara Łopienna i okolicy w pótnocnej Wielkopolsce, Kraków.

Turska H. (1982), O powstaniu polskich obszarów językowych na Wileńszczyźnie, „Studia nad polszczyzną kresową", t. I, s. 19-121.

Walicki A. (1886), Błędy nasze w mowie i piśmie ku szkodzie języka polskiego popetniane oraz prowincjonalizmy, wyd. 3, Kraków - Warszawa.

Waniakowa J. (2006a), Nazwy niezapominajki (Myosotis) w gwarach polskich jako przyktad ekspansji slownictwa literackiego, [w:] Studia Dialektologiczne, t. III, red. J. Okoniowa, Kraków, s. 71-79.

Waniakowa J. (2006b), The Forget-me-not, Vergißmeinnicht, ne-m'oubliezpas, незабудка a historical and etymological study, [w:] Proceeding of the 4th International Congres of Dialectologists and Geolinguists, ed. A. Timuška, Riga, s. 527-534.

Waniakowa J. (2012), Polskie nazwy dziko rosnacych roślin zielnych na tle słowiańskim, Kraków.

Waniakowa J. (2015), Wybrane nazwy niezapominajki jako czesść wspólnego dziedzictwa europejskiego, „Zeszyty Łużyckie”, 49, s. 205-216. 
Waniakowa J. (2019), Polskie gwarowe nazwy chabra bławatka, Centaurea Cyanus L. na tle stowiańskim i europejskim, „Prace Filologiczne”, LXXIV, s. 173-187.

Wyżycki G.J. (1845), Zielnik ekonomiczno-techniczny czyli opisanie drzew, krzewów i roślin dziko rosnacych $w$ kraju, jako też przyswojonych, z pokazaniem użytku ich $w$ ekonomice, rękodziełach, fabrykach i medycynie domowej, z wyszczególnieniem jadowitych i szkodliwych oraz mogących stużć ku ozdobie ogrodów i mieszkań wiejskich ułożony dla gospodarzy $i$ gospodyń, Wilno.

Zdaniukiewicz A.A. (1972), Gwara Łopatowszczyzny: fonetyka, fleksja, słownictwo, Wrocław.

Вендина Т.И. [Vendina T.I.] (2014), Типология лексических ареалов Славии [Тіроlogiia leksicheskikh arealov], Москва - С.-Петербург.

Грінченко Б. [Hrichenko В.] (1907-1909), Словарь української мови [Slovar' ukrains'koi movi], т. I-IV, Київ.

Гюлумянц К.M. [Giulumianc K.M.] (1982), Некоторые наблюденя над фразеологией польских говоров белорусско-литовской зоны [Nekotorye nabliudenia nad frazeologiei pol'skikh govorov belorussko-litovskoi zony], „Studia nad polszczyzną kresową”, t. I, s. 225-231.

Даль В.И. [Dal' V.I.] (1955-1956), Толковый словарь живого великорусского языка [Tolkovyi slovar' zhivogo velikorusskogo iazyka], т. I-IV, Москва.

ESBM, Этымалагічны слоўнік беларускай мовы [Etymalahichny sloǔnik belaruskai movy], рэд. В.У. Мартынаў, Г.А. Цыхун, Мінск, 1978-.

LAB, Лексічны атлас беларускіх народных гаворак у пяиі тамах [Leksichny atlas belaruskikh narodnykh hovorak u piaci tamakh], рэд. М.В. Бірыла, Юзэфа Ф. Мацкевіч, Мінск, 19931998.

OLA III, Общеславянский лингвистический атлас [Obshsheslavianskij lingvisticheskij atlas], Серия лексико-словообразовательная, вып III: Растительный мир, ред. А.А. Падлужны, А.А. Крывіцкі, Минск 2000.

OLA IV, Общеславянский лингвистический атлас [Obshcheslavianskij lingvisticheskij atlas], Серия лексико-словообразовательная, вып. IV: Сельское хозяйство, red. A. Ferenčíková (vedecká redaktorka), M. Chochol, H. Jenč, L'. Králik, J. Siatkowski, Ž.Ž. Varbot, P. Žigo, Bratislava 2012.

PolGov, Польские говоры в CCCP [Pol'skie hovory v SSSR], ч. I: Исследования и материаль 1967-1969, ч. II: Исследования и материаль 1969-1971, Минск 1973.

SPZB, Слоўнік беларускіх гаворак паўночна-заходняй Беларусі і яе пагранічча у пяиі тамах [Sloǔnik belaruskaj havorak paŭnochna-zahodniaj Belarusi i iae pagranicha u piaci tomakh], рэд. Ю.Ф. Мацкевіч, т. I-V, Мінск 1979-1986.

SRJ XI-XVII, Словарь русского языка XI-XVII вв. [Slovar' russkogo iazyka XI-XVII vv.], ред. С.Г. Бархударов, Ф.П. Филин, Д.Н. Шмелев, Г.А. Богатова, В.Б. Крысько, Р.Н. Кривко, Москва 1975-.

SRJ XVIII, Словарь русского языка XVIII века [Slovar' russkogo iazyka XVIII veka], ред. Ю.С. Сорокин, 3.М. Петрова, Ленинград - С.-Петербург 1984-.

SSRLJ, Словарь современного русского литературного языка [Slovar' sovremennogo russkogo literaturnogo iazyka], ред. Ф.П. Филин, т. I-XVII, Москва - Ленинград 19501965.

SUM XVI-XVII, Словник украӥнської мови XVI - першої половини XVII cm. [Slovnik ukrains'koi movi XVI - pershoi polovini XVII st.], ред. Д.Г. Гринчишин, Львів 1994-. 
SUM, Словник української мови [Slovnik ukrains'koi movi], ред. І.К. Білодід, I-XI, Київ 1970-1980.

Сабадош I. [Sabadosh I.] (2015), Украӥнська лексика в просторі і часі [Ukrains'ka leksika $v$ prostori $i$ chasi], Ужгород.

TSBM, Тлумачальны слоўнік беларускай мовы [Tlumachal'ny sloǔnik belaruskaj movy], рэд. К.К. Атраховіч, К. Крапіва, т. I-V, Мінск 1977-1984.

Фасмер М. [Fasmer М.] (1964-1973), Этимологический словарь русского языка [Etimologicheskij slovar' russkogo iazyka], перевод с нем. и дополнения О.Н. Трубачева, т. I-IV, Москва. 